\title{
Willem Banning and the Reform of Socialism in the Netherlands
}

\author{
Arie L. Molendijk \\ University of Groningen, Faculty of Theology and Religious Studies, Oude Boteringestraat 38, Groningen, 9712GK, \\ The Netherlands \\ a.1.molendijk@gmail.com
}

\begin{abstract}
In 1947 the liberal Protestant minister Willem Banning drafted a new programme for the Labour Party, in which the party dropped the Marxist view of history and class struggle. New Labour in the Netherlands was envisioned as a party that strove for a democratic and just society. Banning's role in reforming the Labour Party was part of his broader project of breaking down structures of socio-political segregation that had existed since the end of the nineteenth century. Banning argued that the Labour Party had to abandon its atheist ideology to open up to Protestants and Catholics. This article will examine Banning's views and ideals and show how he contributed to the transformation of Labour into a social democratic party and seek answer to the question: how could a liberal Protestant minister become the main ideologue of the Labour Party?
\end{abstract}

\section{Introduction}

A touching photograph shows Willem Banning being decorated by Prime Minister Willem Drees on the occasion of his sixty-firth birthday in February 1953. The demeanour of the two social democrats displays a degree of ambiguity: they both seem to be fully enjoying this special moment, while at the same time being sceptical of such honours. In his words of gratitude Banning said that his resistance had been overcome by his friends' insistence that he should accept the distinction. ${ }^{1}$ The Dutch Labour Party could not have been what it was in the 1950s without the decisive input of Drees and Banning. Drees was the practical builder, less interested in Banning's ideological views that steered the party away from its Marxist roots. But he was, of course, fully aware of his 'comrade's' input into modernising Labour, which had enabled him - Drees - to become the first social democratic prime minister of the Netherlands (1948-58).

The liberal Protestant minister Willem Banning (1888-1971) made a significant contribution to the transformation of the old Social Democratic Workers' Party (Sociaal-Democratische Arbeiderspartij; SDAP) into a broader people's party, the Partij van de Arbeid (PvdA), which was established in $1946 .{ }^{2} \mathrm{He}$ had the honour of presiding over its first congress and famously claimed in his opening speech: 'we are bound together . . . by the responsibility for our whole people in distress, we are bound together by the will for social justice and freedom, we are bound together by the firm intention to make a common new beginning. A breakthrough has been made, there is a new beginning, a new path is opened. Here we have - the Labour Party'. ${ }^{3}$ From a present-day perspective, these words may

${ }^{1}$ H. van Wirdum-Banning, Willem Banning 1888-1971. Leven en werken van een religieus socialist (Amersfoort-Leuven: De Horstink, 1988), 163-4.

2 H.M. Ruitenbeek, Het ontstaan van de Partij van de Arbeid (Amsterdam: Arbeiderspers, 1955).

3 Banning, 'Openingsrede van den voorzitter Prof. Dr. W. Banning', Het Nieuwe Begin. Verslag van het Stichtingscongres van de Partij van de Arbeid (Amsterdam: Partij van de Arbeid, 1946), 5-16, here 15-6.

(C) The Author(s) 2020. This is an Open Access article, distributed under the terms of the Creative Commons Attribution-NonCommercialShareAlike licence (http://creativecommons.org/licenses/by-nc-sa/4.0/), which permits non-commercial re-use, distribution, and reproduction in any medium, provided the same Creative Commons licence is included and the original work is properly cited. The written permission of Cambridge University Press must be obtained for commercial re-use. 
sound somewhat overly optimistic, but after the devastation of the Second World War many people hoped for a renewal of Dutch society and politics that would overcome old confessional distinctions and divisions.

\section{Appraisal and Research Question}

Notwithstanding his merits and achievements, Banning has not always been remembered favourably. The most famous and influential attack on him was Jan Rogier's scathing portrayal of this 'missionary of Dutch liberal Protestantism', who had transformed the socialist movement into a religio-ethical elite that resembled Frank Buchman's anti-communist Moral Re-Armament Group. Rogier described Banning as an authoritarian thinker with a dubious preference for hierarchy and elites. According to this view, Banning's restorative course of action and thinking had nothing to do with true socialism. ${ }^{4}$ The fact that he was a Protestant minister was emphasised to discredit his contribution. ${ }^{5}$ This dismissive tone and critical approach were not limited to left-wing journalists and academics. In a commemorative meeting in 1987, the former prime minister Joop den Uyl (1919-87), who had worked closely with Banning on writing Labour's 1959 party manifesto, called him a relic of the nineteenth century who was deeply steeped in unconditional optimism about progress. ${ }^{6}$

Political historians of the Netherlands also have a tendency to criticise Banning and accuse him of vagueness, referring to his attempts to furnish socialism with moral underpinnings. In one of the more balanced and favourable assessments of his role, the 'reformists' Banning and his friend Koos Vorrink (1891-1955), the later chairman of the SDAP, were said - 'despite their often bizarre language' - to probably have best understood the direction that Labour should go during the heated debates of the 1930s on the renewal of the party. ${ }^{7}$ This quote illustrates the difficulty of understanding why Banning was so influential. Some claimed that he was important ideologically, but not politically, ${ }^{8}$ and others saw him as a 'weak brother' in terms of his political skills.'

This sentiment could turn rather nasty: Marinus van der Goes van Naters (1900-2005), an old 'friend' from the 1930s, later called him a 'vain man with a somewhat curiously fascinating influence, who by formulating the idea of a "personalist socialism" succeeded in winning over members for the PvdA who originally did not belong there. ${ }^{10}$ In particular, the personalism that Banning articulated in 1942-3 was seen as a watered-down form of socialism, or at least a depoliticisation of socialism. ${ }^{11}$ The

4 Jan Rogier, Een zondagskind in de politiek en andere christenen. Opstellen over konfessionele politiek in Nederland van Colijn tot Cals (Nijmegen: SUN, 1980), 103-12. The essay was originally published in 1968. For an overview of this type of criticism see Dick Pels, 'Willem Banning. Voor en tegen', Negende Jaarboek voor het democratisch Socialisme (Amsterdam: Wiardi Beckman Stichting, 1988), 145-9; Rob Hartmans, 'Het socialisme van Willem Banning. Bij de honderdste geboortedag van een "vergeten” ideoloog', Socialisme en Democratie, 45, 1 (1988), 8-14.

5 Anet Bleich, Een Partij in de Tijd. Veertig jaar Partij van de Arbeid 1946-1986 (Amsterdam: De Arbeiderspers, 1986 ), 24.

6 Bert Barends, 'Creatieve gerechtigheid. Heeft Banning ons nog iets te zeggen', Tijd \& Taak, 15 May 1987, 9 (vooruitgangsoptimisme). Because of strong protests from the audience Den Uyl somewhat retracted this strong statement later in the discussion.

7 H.F. Cohen, Om de vernieuwing van het socialisme. De politieke oriëntatie van de Nederlandse sociaal-democratie 19191930 (Leiden: Universitaire Pers Leiden, 1974), 242.

8 Frans Becker, 'De ideologische en programmatische ontwikkeling van de PvdA', in Frans Becker \& Gerrit Voerman, eds., Zeventig jaar Partij van de Arbeid (Amsterdam: Boom, 2016), 134; Cohen, Om de vernieuwing van het socialisme, 239; Remieg Aerts et al., Land van kleine gebaren. Een politieke geschiedenis van Nederland 1780-1990, second edition (Nijmegen: Sun, 2001), 240: 'curiously apolitical'.

9 J. de Kadt, Politieke herinneringen van een randfiguur (Amsterdam: Van Oorschot, 1976), 66-7.

10 Jan Bank and Stef Temming, eds., Van brede visie tot smalle marge. Acht prominente socialisten over de SDAP en de PvdA (Alphen aan de Rijn: Sijthoff, 1981), 124.

11 S.A.J. (Sjoerd) van Faassen, 'Ten koste van de helderheid. De overgang van De Socialistische Gids to Socialisme en Democratie', Tweede Jaarboek voor het Democratische Socialisme (Amsterdam: Arbeiderspers, 1980), 155; Bart Tromp, Het sociaal-democratisch programma. De beginselprogramma's van SDB, SDAP, PvdA 1878-1977: een onderzoek naar de ontwikkeling van een politieke stroming (Amsterdam: Bert Bakker, 2002), 195-6; see Piet de Rooy's ironic remarks in Republiek van rivaliteiten. Nederland sinds 1813 (Amsterdam: Mets \& Schilt, 2002), 204-8. 
fact that he wielded a fair degree of influence was explained in personal terms and attributed to his charisma or even, somewhat maliciously, to his 'sex appeal to men and women alike'. ${ }^{12}$

Notwithstanding his 'vagueness' and allegedly 'apolitical' position, Banning succeeded in convincing the majority of his fellow party members that the materialist Marxist principles should be replaced by an approach that centred on the struggle for a democratic and just society, addressing the needs of individuals. I will argue that Banning's role in reforming the Labour Party was part of his broader project of breaking down structures of socio-political segregation that had existed since the end of the nineteenth century. Dutch society was divided into separate cultural, political and social spheres based on confession or world view. The three main 'pillars' were Catholic, Protestant and Social Democratic. Banning promulgated the 'breakthrough' (Doorbraak), which ultimately aimed to break down these pillars. His primary aim was to convince Christian workers to vote Labour.

Given the opposition to Banning's religious socialism, we have to ask how he became the party's main ideologue. Without going into detail about the day-to-day political struggle, this article will focus on his outstanding intellectual contribution to the reform of the SDAP and the foundation of the PvdA. To put his contribution into a broader perspective, I will also address the background and international context of his work. Formative influences deserve special attention here. What did he read, what did he think of classical Marxism and reformers such as Hendrik de Man? Firstly, I will present a biographical sketch concentrating on the beginnings of his intellectual path; secondly, I will analyse his contribution to the new direction that Labour took; thirdly, I will discuss his later views on 'personalist socialism' and the Doorbraak and, finally, I will explain his role and tremendous success as party ideologue. Like Hendrik de Man in Belgium, Banning was a key player in the reformation and transformation of the Dutch socialist party into a modern social democratic party.

\section{Willem Banning - Life and Work}

On the occasion of his seventieth birthday, Banning wrote a short autobiography called 'Retrospective' (Terugblik). It was not for sale, but he distributed it among friends with whom he had worked mainly within religious and social organisations - to improve the fate of the working class and to enlighten the middle classes about the injustice of the economic exploitation of workers. The booklet was intended to shed light on the life and struggle of at least a part of the generation that was young and idealistic at the beginning of the twentieth century'. This long subtitle conveys a sense of nostalgia, and probably also disillusionment. The booklet shows how Banning framed his life and work, and it must be interpreted with caution. His narrative highlights economic and social circumstances and stresses the role of 'coincidence' in his life. I will use other sources to put this view into perspective. ${ }^{13}$

Banning began by describing his upbringing in a working-class family in a village on the shores of an inland sea in the north of the Netherlands. Each spring some fifty men - his father among them went to sea to fish for herring on the West Coast, returning by early December. The Banning family lived in a 'side-alley of an alley', sharing two rooms and an attic, where peat was stored for the winter and where Willem, who liked school, spent happy hours reading books from the library. The family was proud of the fact that they did not require support from the church. Although strong social oppositions existed within the community, they did not lead to the formation of a socialist group. Banning

12 Peter Jan Knegtmans, Socialisme en Democratie. De SDAP tussen klasse en natie (1929-1939) (Amsterdam: Stichting beheer IISG, 1989), 89; Coos Huijsen, Socialisme als opdracht. De religieus-socialistische Arbeiders Gemeenschap der Woodbrookers en de PvdA. De geschiedenis van een relatie (Baarn: Anthos, 1986), 37 (letter dated 20 Feb. 1985 by Van der Goes van Naters to the author).

13 Banning, Terugblik. Op leven en strijd van althans een deel der generatie die idealistisch-jong was aan het begin der twintigste eeuw toegelicht aan de ontwikkelingsgang van één hunner (Amsterdam: Arbeiderspers, 1958). The text is reprinted in Terugblik en perspectief. Willem Banning 1888-1971. Bannings 'Terugblik' ingeleid door dr. J.M. van Veen, met bijdragen van prof.dr. A. van Biemen, dr. J.M. van Veen, dr. H.D. de Loor en ds. L.H. Ruitenberg (Baarn: Bosch \& Keuning, 1972); Herman Zunneberg, Willem Banning 1888-1971. Een onderzoek naar de verhouding van zijn spiritualiteit tot zijn sociaal-politiek engagement, $\mathrm{PhD}$ thesis Utrecht, 1978 and Van Wirdum-Banning, Banning. 
attended a public (i.e. non-confessional) school with the children of factory owners and local dignitaries such as the physician and notary. 'Our children's crushes were not bothered by class distinctions'. ${ }^{14}$

The plan was for Willem to go to sea with his father after finishing primary school, but instead he was given an opportunity for further education. His small stature, a less-than-strong constitution and his intellectual abilities will have made this decision easier, but it meant a financial sacrifice. Banning does not refer to these expenses, but his siblings recalled that there was a nest egg for Willem. ${ }^{15}$ Thus, he was prepared to become a primary school teacher. Teacher training colleges were the first stepping stone for children from working-class and lower middle-class families to receive an education, which was largely funded by the government. ${ }^{16}$ In 1903 Banning moved to the Haarlem school, where - in his own words - he first had to overcome his dialect, his poor manners and his unfounded sense of respect for hierarchical relationships. ${ }^{17}$ There, he must have acquired an awareness of his class background, which may have sparked his emerging anti-bourgeois attitude.

During his Haarlem years, Banning became involved in the youth movement and advocated teetotalism. ${ }^{18}$ For Banning, the youth movement brought not only a sense of community and a 'reverence for the Mystery of Life', but also a radical ascetic form of idealism to strive for a better world. ${ }^{19}$ After obtaining his teacher's diploma, Banning got a job as tutor to the youngest son of a notary in Hoorn. There, he was influenced by the 'red' Protestant minister J. Th. Tenthoff (1847-1916), who had publicly defended the workers' cause as early as the 1880 s and 1890 s. ${ }^{20}$ Banning was introduced to a group of socialist ministers in the Dutch Reformed Church who were associated with the Christian-socialist weekly The Joyful World (De Blijde Wereld). In his retrospective, Banning speaks about his goal to educate and uplift the common people as part of his religious calling. ${ }^{21}$ It was during his Hoorn period that he decided to become a minister and to prepare for the necessary exams. He enrolled at the theological faculty at Leiden University in $1913 .^{22}$

Banning's future wife Han Schoemaker was also involved in the socialist movement. She was a member of the SDAP, joined shortly afterwards in 1914 by Banning, who was deeply disturbed by the unexpected outbreak of the Great War. ${ }^{23}$ In the summer of 1914 they studied Karl Marx's Das Kapital and Karl Kautsky's edition of the Erfurter Programm together, which at the time functioned as an introduction to socialist thought. It is even called a 'catechism' in the subtitle of the Dutch translation. ${ }^{24}$ In Banning's retrospective, Henriëtta Johanna Wilhelmina Schoemaker (1899-1965) is promoted within the space of two pages - with no further explanation - from 'fiancée' to 'wife'. Banning must have been aware of her decisive role in his life, but he seems to have preferred to steer away from more intimate matters and to take her contribution to his career as a matter of course. Friends deplored the fact that this gifted woman, who was herself a teacher, devoted her life to her husband and the causes they both stood for. ${ }^{25}$ Their marriage took place on 9 October 1915. They considered it an administrative formality, and on the occasion Willem wore sandals and a cape (the usual attire within the youth movement at the time). Initially, there was no room for children and the couple practised family planning; later, three daughters were born. ${ }^{26}$

14 Banning, Terugblik, 8.

15 Van Wirdum-Banning, Banning, 25.

16 Ibid., 25.

17 Banning, Terugblik, 10.

18 Van Wirdum-Banning, Banning, 33.

19 Banning, Terugblik, 14.

20 http://www.oudhoorn.nl/biografie/biografie_johannes_theodorus_tenthoff.php; Zunneberg, Banning, 63.

21 Van Wirdum-Banning, Banning, 39; Banning, Terugblik, 16-7.

22 Van Wirdum-Banning, Banning, 49.

23 Ibid., 54.

24 Banning, Terugblik, 23. Karl Kautsky, Het Erfurter Programma in zijn hoofdpunten toegelicht (Catechismus der Sociaal-Demokratie), translated by C. van Gelder (Amsterdam: S.L. van Looy, 1901).

25 Van Wirdum-Banning, Banning, 43-8.

26 Ibid., 55-6. 
Along with the classics of Marxist theory, Banning's retrospective mentions Brailsford's The War of Steel and Gold (1914) as the book that had given him a deeper understanding of the meaning of 'imperialism'. ${ }^{27}$ Henry Noel Brailsford (1873-1958) was a famous left-wing British journalist whose work was well-known in the Netherlands. The War of Steel and Gold appeared in Dutch, as did After the Peace (1920), his critique of the Treaty of Versailles, with the title in Dutch 'How to Save Europe. ${ }^{28}$ Many Dutch religious socialists found German historical materialism too narrow and welcomed the contribution of British authors, such as the nineteenth-century public intellectuals and reformers Thomas Carlyle, Charles Kingsley and Frederick Denison Maurice. They were also inspired by contemporary socialists, especially the group around the Union of Democratic Control, including the journalists Brailsford and Edmund Dene Morel and the Labour politicians Norman Angell and Ramsay MacDonald. ${ }^{29}$ The Union, founded in 1914, pleaded for disarmament and international cooperation and supported the idea of a league of nations. ${ }^{30}$

In his autobiography Banning further emphasises the influence of his Leiden professors. The religious historian and ethicist Pierre Daniel Chantepie de la Saussaye (1848-1920), allegedly the richest man in Leiden, taught him the importance of historical analysis. ${ }^{31}$ Elsewhere, Banning mentioned the writings of Wilhelm Dilthey and Ernst Troeltsch, which helped him to understand the role of the natural sciences and capitalism in shaping the modern world. ${ }^{32}$ For his severe criticism of the bourgeois mentality, Banning referred not only to Marx's analysis of worker alienation, but also to idealist philosophers and theologians who sought norms and values in the maelstrom of history. ${ }^{33}$ In this respect Banning valued above all others his Leiden teacher, the systematic theologian Karel Hendrik Roessingh (1886-1925). Roessingh was strongly influenced by the Baden School of Neo-Kantianism (Wilhelm Windelband, Heinrich Rickert, Troeltsch). Banning found there a critical philosophy of universal values that acknowledged a transcendent reality, which believers experienced as the holy presence of God. The acknowledgement of values and the concomitant rejection of a materialistic worldview determined Banning's thinking. He saw religion as quintessential, as a force to transform and transcend this world. ${ }^{34}$

On 18 November 1917 Banning was confirmed as a Dutch Reformed minister in Haarlo, a village in the east of the Netherlands near the German border. There Banning and his wife became involved in the Dutch Woodbrooke Society, which convened in nearby Barchem and is also known as the Barchem movement. ${ }^{35}$ The Woodbrooke Society was founded in 1908 by theologians who had visited the Quaker Study Centre in Selly Oak (near Birmingham) and were inspired by Quaker spirituality and social engagement. The British settlement was established in 1903 and had a 'Dutch connection' from the very beginning. The biblical scholar James Rendel Harris (1852-1941) had turned down a professorship at the Leiden theological faculty to become the first director of studies at Woodbrooke. Rendel Harris took the opportunity to invite students from Leiden and other Dutch universities and many took up the offer (Roessingh was one of them). By 1935194 Dutch students had spent a term at

27 Henry Noel Brailsford, The War of Steel and Gold. A Study of the Armed Peace (1914), sixth edition (London 1916), 7-8.

28 Brailsford, De oorlog van staal en goud. Eene studie omtrent den gewapenden vrede (Zutphen: Thieme, 1914); Brailsford, Hoe redden wij Europa? (Amsterdam: Elsevier, 1920); Brailsford, Het Socialisme - Nu (Amsterdam: Querido, 1927).

29 Marjet Brolsma, 'Het humanitaire moment'. Nederlandse intellectuelen, de Eerste Wereldoorlog en het verlangen naar een regeneratie van de Europese cultuur (1914-1930) (Hilversum: Verloren, 2017), 102-3; Hilda Verwey-Jonker, 'Vijf en twintig jaar socialistische theorie', in E. Boekman et al., eds., Ir. J.W. Albarda. Een kwart eeuw parlementaire werkzaamheid in dienst van de bevrijding der Nederlandsche arbeidersklasse (Amsterdam: Arbeiderspers, 1938), 330-48, here 337.

30 See, for instance, Sally Harris, Out of Control: British Foreign Policy and the Union of Democratic Control, 1914-1918 (Hull: University of Hull Press, 1996); Henry Noel Brailsford, A League of Nations (1916), second revised edition (London: Headley Bros, 1917).

31 Banning, Terugblik, 19.

32 Banning, Om de groei der gemeenschap (Arnhem: Van Loghum Slaterus, 1926), 7.

33 Ibid., 179-87.

34 Banning, Terugblik, 21.

35 For a good overview of the Barchem movement: J. Lindeboom, Geschiedenis van de Barchem-beweging 1908-1958 (Lochem: Barchem-beweging, 1958). 
Woodbrooke. ${ }^{36}$ Woodbrooke at that time was largely the creation of Rendel Harris, who had found inspiration in the revival movement. It was an inclusive ecumenical community that cultivated spirituality, prayer and meditation. Participants were also keenly aware of the social issues caused by ongoing industrialisation and the capitalist mode of production. ${ }^{37}$ The Great Depression of the 1930s caused a deep decline in production and massive unemployment. In 1935 almost 20 per cent of the Dutch working population was unemployed.

'Barchem', the Dutch counterpart, was inspired by Woodbrooke. Barchem was a Protestant education centre avant la lettre. Lectures and courses on a wide variety of themes were presented in a religious context, including prayer and meditation meetings. The Barchem movement started with courses for laypeople who were interested in theology, but workers, unemployed people and businesspeople also took part. The goal was to encourage personal, cultural and religious development, and to strengthen social engagement. This latter aspect became even more important when the Workers' Community of the Woodbrookers was constituted in 1919 as part of the Woodbrooke Society. Based on a socialist interpretation of Christianity, the Workers' Community supported the working class. ${ }^{38}$

In 1931, shortly before finishing his dissertation on the social ethics of the French socialist leader Jean Jaurès, ${ }^{39}$ Banning had become director of Barchem. He prided himself on being an 'educator of the people'. ${ }^{40}$ He proved to be an effective organiser, fundraiser and teacher. Barchem was the centre of his existence for several decades, during which time he considerably expanded its activities and outreach. ${ }^{41}$ However, Banning's influence was not confined to the Woodbrookers. He travelled across the country giving lectures, taught courses (in particular at the Amsterdam School for Social Work) and took part in various summer schools. ${ }^{42}$

In the Second World War the buildings at Barchem were commandeered by the Germans and Banning accepted a call to become a minister in Haarlem. On 2 May 1942 he was arrested and imprisoned in a hostage camp in Sint Michielsgestel in the south of the Netherlands. Prominent Dutch intellectuals and politicians were kept hostage here. Although a couple of prisoners were executed as revenge for resistance activities, generally they enjoyed considerable freedom, and Banning organised lectures, meetings and discussions about the future of the Netherlands. ${ }^{43}$ After the war his main occupation was as director of Church and World (Kerk en Wereld), the newly founded institution of the Dutch Reformed Church that trained laypeople to support renewal among local congregations.

In 1946 Banning was also appointed as part-time professor in the sociology of religion at the Leiden theological faculty. ${ }^{44}$ In 1936 he had written one of the first Dutch introductions to the field, and in 1938 he had published a popular handbook on new social movements. ${ }^{45}$ In the 1950 s he conducted

36 G.L. van Dalfsen, 'The Influence of Woodbrooke in the Netherlands', Woodbrooke 1903-1953, 159-68.

37 Lindeboom, Geschiedenis van de Barchem-beweging, 4-6; Herbert G. Wood, 'First Director of Studies', in Robert Davis, ed., Woodbrooke 1903-1953: A Brief History of a Quaker Experiment in Religious Education (London: Bannisdale Press, 1953), 19-30; Zunneberg, Banning, 67; Van Wirdum-Banning, Banning, 90. In 1931 Banning would spend a couple of weeks at the Quacker settlement.

38 Huijsen, Socialisme als opdracht, 22-9, 45-57. Maarten van den Bos, Geloven in het ideaal. Geschiedenis en actualiteit van de Arbeidersgemeenschap der Woodbrookers (Hilversum: Verloren, 2019).

39 Banning, Jaurès als denker (Arnhem: Van Loghum Slaterus, 1931).

40 Banning, Terugblik, 52.

41 H.J. Wilzen and A. van Biemen, Samen op weg. Vijftig jaar ontmoeting tussen Christendom en Socialisme in De Blijde Wereld en Tijd en Taak (Amsterdam: Arbeiderspers, 1953); Coos Huijsen, Socialisme als opdracht, 58-70; B.J. Hake, 'The Dutch Woodbrookers' Movement and the Development of Residential Adult Education in the Netherlands, 1903-41', History of Education, 25 (1996), 335-51.

42 Van Wirdum-Banning, Banning, 89, 99.

43 Madelon de Keiser, De Gijzelaars van Sint Michielsgestel. Een elite-beraad in oorlogstijd (Alphen aan den Rijn: Sijthoff, 1979).

44 Banning retired from this position in 1958.

45 Banning, Theologie en Sociologie. Een terreinverkenning en inleiding (Assen: Van Gorcum, 1936); Banning, Hedendaagse sociale bewegingen. Achtergronden en beginselen (Arnhem: Van Loghum Slaterus, 1938). The revised thirteenth edition was published by H.E.S. Woldring in 1998; see Van Wirdum-Banning, Banning, 89, 99. 
and supervised an extensive survey of religious and ecclesiastical life in the context of economic and social structures, which varied considerably across the provinces of the Netherlands. ${ }^{46} \mathrm{He}$ also initiated the Sociological Institute connected to Kerk en Wereld, which the General Synod of the Dutch Reformed Church would close in 1968. At the end of his life Banning was increasingly concerned about the 'power of restorative tendencies in the [Dutch Reformed] Church'. ${ }^{47}$

Banning had an enormous capacity for work. For the period 1945 to 1965 alone, I have counted some sixty to seventy independent publications (books, brochures and editions of lectures), which he wrote alongside his practical work as director of Kerk en Wereld and his teaching in Leiden. ${ }^{48}$ His stable marriage, ascetic inclinations (no smoking or drinking) and work ethos helped him to achieve a considerable amount. He was probably the wrong type of person to be fully appreciated in the 1960s, when the on-going emancipation of workers and other groups led to consumerism and a more hedonist lifestyle. ${ }^{49}$ Banning became seriously ill in 1965, which put an end to his working life. He died on 7 January 1971.

\section{Religious Socialism and Reforming the SDAP}

'Religious socialism' was, of course, not an obvious combination. Traditional Marxists, who saw religion as the product of a false consciousness, found it a contradictio in terminis, and the Christian churches condemned atheist socialism. Marxist parties generally rejected Christianity. This was also true in France, despite the religious inclinations of their former leader Jean Jaurès (1859-1914). But there were socialists in the United Kingdom and the Scandinavian countries who thought otherwise, and who considered the Christian faith to be the very foundation of their socialist convictions. This did not necessarily amount to much direct political influence, but religious socialists played a considerable role in the socialist movement in the Netherlands. In the mid-1920s religious socialists were a recognisable group within the SDAP. ${ }^{50}$ Banning had become their undisputed leader within a very short span of time. As editor of Time and Task (Tijd en Taak), the journal of the religious socialists, he reached a relatively broad audience. By the 1930s there would be 3,000 to 3,500 subscribers, more than for the SDAP journal. ${ }^{51}$

What views did Banning propose? First and foremost, he argued for moving beyond Marxism. $\mathrm{He}$ did not consider Marxism tenable as a materialist world-view because its nineteenth-century rationalistic and optimist presuppositions were no longer valid almost a hundred years later. From an economic perspective, Banning considered Marxism to be one-sided, and from a philosophical point of view, it denied the constitutive element of value formation. Moreover, it did not do justice to the tragic aspect of human life. ${ }^{52}$ While the economic base remained important, Banning insisted that it did not drive the course of history by itself: ideals and values also mattered. Furthermore, the old proletarian worldview was too intimately connected with class resentment to be of any real use. Moral resources were needed, as well as an awareness of the togetherness of all human beings and a faith in transpersonal values, fundamentally religious phenomena according to Banning. ${ }^{53}$

\footnotetext{
46 Banning, Handboek Pastorale Sociologie, 7 vols ('s-Gravenhage: Boekencentrum, 1953-1962).

47 Banning, Terugblik, 67; see L. Laeyendecker, 'Banning. Sociologie, Kerk en Theologie', in M.B. ter Borg, ed., Banning als denker (Utrecht: De Ploeg, 1988), 52-72.

48 For bibliographical information see Zunneberg, Banning. A complete list of his publications is still a desideratum.

49 Rob Hartmans, H. Noordegraaf and R.E. van der Woude, 'Willem Banning (1888-1971). Opvoeder van het volk', in Paul E. Werkman \& Rolf van der Woude, eds., Bevlogen Theologen. Geëngageerde predikanten in de negentiende en twintigste eeuw (Hilversum: Verloren, 2012), 287-315, 311-2.

50 Cohen, Om de vernieuwing, 200-1.

51 Willem Bouwman, 'Tijd en Taak. Blad voor Bannings idealen', in G. Harinck \& D.Th. Kuiper, eds., Anderhalve eeuw protestantse periodieke pers (Zoetermeer: Meinema, 1999), 108-34; Knegtmans, Socialisme \& Democratie, 89. The old weekly De Blijde Wereld was continued in 1932 as Tijd en Taak.

52 Banning, Marx. . . en verder, Religieus-socialistische vragen. Uitgavenreeks van de arbeidersgemeenschap der 'Woodbrookers in Holland', IV/ 2-3 (Arnhem: Van Loghum Slaterus, 1932), 132.

53 Banning, Marx ... en verder, 134-5.
} 
Banning argued that socialism nowadays needed a spiritual renewal. He opposed the bourgeois satisfait, who was materialistic, had no concern for higher ideals and thanked God for his own good behaviour. ${ }^{54}$ Young religious socialists often spoke about the conflict between generations and the need for a new type of 'man'. 55 Notwithstanding this critique of the bourgeois mentality, Banning did not limit his socialist ideals to the working (and lower-middle) classes. In order to grow, the SDAP needed a broader constituency. He saw the rise of national socialism during the 1930 s as proof that the emergence of a classless and just society could not be taken for granted. At a very early stage Banning not only condemned national socialism but also presented an analysis of the causes of its success, giving a detailed overview of its attraction to various social groups and pointing to the failings of German socialism in this respect. ${ }^{56}$ In his view, a renewed socialism needed sources of inspiration, convincing symbols and narratives and even a touch of nationalism in order to appeal to larger groups. This does not mean that Banning's socialism can be characterised as idealist and vague. Although he did have the lofty ideal of creating a 'community of humanity', he was equally outspoken about the need to socialise the means of production and property. ${ }^{57}$

In 1926, at a time when Banning was forming his religious socialist views, Hendrik de Man's The Psychology of Socialism (Zur Psychologie des Sozialismus) appeared. The study caused quite a stir and made a deep impact on socialists and religious socialists in particular. Banning wrote that he had spent very happy hours reading the book, which he found very useful. ${ }^{58}$ According to Banning, Hendrik de Man (1885-1953) neither promoted socialism with a religious flavour nor a religious conviction with some socialist ingredients, but defended a genuine form of religious socialism. In his review Banning stated that the book implied an inner revolution, which would not be readily accepted by Marxists in the SDAP. ${ }^{59}$ It is not enough to refer to economic interests alone, Banning claimed; it is de Man's acceptance of the need for a moral imperative to change the world that implies a revolution in socialist thought.

The Belgian socialist Hendrik de Man was a key figure in the international socialist movement who also had quite some influence in the Netherlands. He wrote a letter of encouragement to the first Dutch Religious-Socialist Congress, held in Amsterdam in October $1927 .{ }^{60}$ The congress was attended by some 600 participants, with Banning as one of the key speakers. The importance of this event was even acknowledged by Marxists within the SDAP. ${ }^{61}$ De Man also initiated an international conference in Heppenheim in 1928, where the two men met in person for the first time. ${ }^{62}$ At this and other international meetings - in Barchem (1924), Eisenach (1924), Cologne (1925, 1929) and Le Locle (in the Jura mountains, 1928) - Banning exchanged ideas with other religious socialists from abroad, such as André Philip, Herbert Stead, Paul Tillich, Martin Buber and Leonhard Ragaz. ${ }^{63}$

Banning was not only active within religious socialist circles, he also tried to get his ideas accepted in the SDAP. Starting in 1926 he propagated his views in the socialist newspaper The People (Het Volk), where he polemicised with the orthodox Marxist Frank van der Goes. ${ }^{64}$ Although religious

\footnotetext{
54 Banning, Om de groei der gemeenschap, 180-1.

55 Banning, Als een goed instrument (Amsterdam: Ploegsma, 1946), 91-2; Van Wirdum-Banning, Banning, 46.

56 Banning, Het Nationaal-Socialisme, Religieus-socialistische vragen. Uitgavenreeks van de arbeidersgemeenschap der 'Woodbrookers in Holland', IV/ 1 (Arnhem: Van Loghum Slaterus, 1932); Rob Hartmans, Vijandige Broeders? De Nederlandse sociaal-democratie en het nationaal-socialisme 1922-1940 (Amsterdam: Ambo, 2012).

57 Banning, Onze Boodschap, Geschriften van de Arbeiders-Gemeenschap der 'Woodbrookers in Holland', 21 (Amsterdam: s.e., ca. 1930), 10.

58 Hendrik de Man, Zur Psychologie des Sozialismus (1926), new revised edition (Jena: Diederichs, 1927).

59 Banning's review of Hendrik de Man, De psychologie van het socialisme (Arnhem: Van Loghum Slaterus, 1927), De Blijde Wereld, 23 July 1927; quoted in Cohen, Om de vernieuwing, 204-5.

60 Cohen, Om de vernieuwing, 205; Pels, 'Banning. Voor en tegen', 163

61 Brolsma, 'Het humanitaire moment', 104.

62 Banning, Terugblik, 41; Cohen, Om de vernieuwing, 205.

63 Van Wirdum-Banning, Banning, 74, 110; Kurt Kaiser, Materialien über den religiösen Sozialismus in Deutschland aus der Zeit von 1938-1933, Inaugural-Dissertation Basel 1962 (Köln: s.e., 1962), 26-8.

64 Pels, 'Banning. Voor en tegen', 138-41.
} 
socialists made up a fairly small group, they became a force to be reckoned with. Prominent socialists, such as the party leader Johan Willem Albarda, welcomed their contribution. ${ }^{65}$ In 1931 Banning was elected member of the executive committee of the SDAP. From the very beginning he insisted that social democrats needed a political system that opposed Mussolini's corporative state, soviet-style communism and bourgeois parliamentarism. This new system would also help to take the wind out of the sails of fascism. ${ }^{66}$

Banning's proposal to set up a committee to revise the principles of the SDAP was accepted in June 1933. The report issued on 26 October 1933 rejected the revision of the old 1912 Leiden declaration. Only four of the fourteen committee members were in favour of a new programme, among them Vorrink and Banning. We can already see in their responses the direction that the SDAP would take in later years. They both argued for the need for a democratic course for the party and for a moral basis of socialism. They said that the SDAP should embrace the Dutch national tradition of freedom and should try to reach both Catholic and Protestant workers, as well as farmers, the middle classes and intellectuals. This proposal already contained the seeds of what would later be called the Doorbraak. ${ }^{67}$

At the SDAP congress in 1934 Banning won the most votes after Albarda. He used his popularity to support new initiatives. During the economic crisis of the early 1930s he had urged the party to establish a research bureau, which would have to develop a plan to reform the economy and to combat the massive unemployment. ${ }^{68}$ In a letter to the executive committee dated 29 September 1935, Banning again pointed to the need for reform. Soon afterwards, Albarda and Vorrink, the recently elected party chairman, proposed a new committee, including young intellectuals who wanted reform. Against strong opposition from the Marxists, the reformers - who called themselves 'Jaurèsists' after the French socialist leader - won the battle for a 'democratic socialism' that rejected the principle of class struggle and accepted a moral foundation of socialism. ${ }^{69}$ To reach this outcome Banning had vetoed an earlier wording, in which the ideas and moral values of socialism can be deduced from a scientific analysis of the development of economic relations. ${ }^{70}$ However, his proposal to include a statement to the effect that religion was a 'positive element in the life of our people' was rejected. ${ }^{71}$ Although Banning could not carry through his ideas in full, the crucial issue of the moral foundation of socialism was accepted.

At the 1937 congress the new SDAP programme as drafted by the Programme Committee was accepted without major changes. The demand for national disarmament, however, was the subject of fierce debate. Although Banning received applause for his pacifist stance, an overwhelming majority (1,509 to 328) supported Albarda's plea to accept the need for a national army. ${ }^{72}$ This was a major issue for Banning: after the Second World War, he would admit that he had been wrong, but at the time he was so devastated that he considered leaving the party. ${ }^{73}$ Notwithstanding this personal defeat, the 1937 congress was a success for Banning, as it implied a major renewal of the party. The 'mates without a fatherland' (vaterslandslose Gesellen), as the socialists were pejoratively called in Wilhelmine Germany, were accepted as fit to govern. In 1939 the SDAP joined a broad coalition of parties under

\footnotetext{
65 Cohen, Om de vernieuwing, 209.

66 Knegtmans, Socialisme \& Democratie, 84-5.

67 Huijsen, Socialisme als opdracht, 75-6; Johan S. Wijne, 'Op weg naar de Partij van de Arbeid. Het beginselprogramma van de SDAP van 1937 en het streven naar een democratisch-socialistische volkspartij', Vierde Jaarboek voor het Democratische Socialisme (Amsterdam: Arbeiderspers, 1983), 148-75, here 154-6.

68 Huijsen, Socialisme als opdracht, 77-9. So-called 'Planism' in the Netherlands was strongly influenced by the ideas of Hendrik de Man and John Maynard Keynes; see Dick Pels, 'Hendrik de Man and the Ideology of Planism', International Review of Social History, 32, 3 (1987), 206-29; Knegtmans, Socialisme \& Democratie, 91.

69 Wijne, 'Op weg naar', 166; Cohen, Om de vernieuwing, 237.

70 Wijne, 'Op weg naar', 166 (conversation with committee member Hilda Verweij-Jonker, 5 Jan. 1981); Tromp, Het sociaal-democratisch programma, 165-6.

71 Wijne, 'Op weg naar', 166.

72 Ibid.; Huijsen, Socialisme als opdracht, 85.

73 Hartmans, Vijandige Broeders?, 225-6; Van Wirdum-Banning, Banning, 105-8; Banning, Terugblik, 54.
} 
prime minister Dirk Jan de Geer from the Christian Historical Union. The fight against rising fascism contributed to the transformation of the SDAP into a democratic people's party, but the ideological ground was prepared by people in the youth movement and religious socialists. ${ }^{74}$

\section{Personalism, the Labour Party and the 'Breakthrough'}

Banning believed that the concept of 'personalist socialism', which he had developed during his internment in Sint Michielsgestel, was especially useful for overcoming ideological differences. In discussions in the camp about the future of the Netherlands, this notion was interpreted in various ways. For Christian participants, for example, it could refer to the need for a more radical 'social-economic reconstruction', whereas for social democrats it indicated the rejection of an exclusively proletarian world-view and an acknowledgement of the priority of the 'community of persons'. ${ }^{75}$ Banning also noted that personalism was a complex phenomenon with diverse roots in European intellectual history. ${ }^{76}$

In twentieth-century European thought the term tends to be associated with the French journal L'Esprit and the work of Emmanuel Mounier, who popularised the concept of 'personalism' in his best-selling book Le Personnalisme. ${ }^{77}$ According to a recent study, Alexandre Marc and Emmanuel Mounier developed much of the personalist and communitarian glossary, and their work is characterised in terms of a conservative revolution and a plea for the return to tradition and community. ${ }^{78}$ However, personalism was a multi-faceted phenomenon, and it is probably better to speak of personalisms in the plural. The Thomist philosopher Jacques Maritain famously stated that there are at least 'a dozen personalist doctrines, which, at times, have nothing more in common than the term "person". ${ }^{79}$ In the 1930 s the personalist spectrum ranged from the far right to socialists. ${ }^{80}$ The dignity of the individual person is key in personalism, which is not to be confused with individualism. Personalism was critical of atomism and materialism, as the individual person had to be seen as connected to community.

From the very start of his career the ideas of personhood and the embedding of the individual within communities were extremely important to Banning. ${ }^{81}$ In The Day of Tomorrow (De Dag van Morgen), written during the war and published in 1945, Banning expanded on his views and articulated a religious form of 'personalist socialism'. Much more strongly than in previous work, he emphasised the role of the Christian faith in overcoming the crises of capitalism and fascism. The moral fight against atomisation and alienation was inspired by his belief in a God who had sacrificed himself to save the world. Thus, Banning outlined a spiritual renewal that was centred on the human person who is held responsible for justice and who must practise love of one's neighbour. ${ }^{82}$

74 Cohen, Om de vernieuwing, 237.

75 Banning, Terugblik, 59.

76 Jan Olof Bengtsson, The Worldview of Personalism: Origins and Early Development (New York: Oxford University Press, 2006).

77 Emmanuel Mounier, Le Personnalisme (Paris: Presses universitaires de France, 1949).

78 Antonin Cohen, 'Why Call it a "European Community"? Ideological Continuities and Institutional Design of Nascent European Organisations', Contemporary European History, 27 (2018), 326-44, 334.

79 Jacques Maritain, La personne et le bien commun (Paris: Desclée de Brouwer, 1947); translation: The Person and the Common Good (New York: Scribner, 1947), Introductory; see Thomas D. Williams and Jan Olof Bengtsson, 'Personalism', in Edward N. Zalta, eds., The Stanford Encyclopedia of Philosophy (Winter 2018 Edition), https://plato.stanford.edu/archives/win2018/entries/personalism/.

80 Samuel Moyn, Christian Human Rights (Philadelphia: University of Pennsylvania Press, 2015), 68-70; Marco Duranti, The Conservative Human Rights Revolution: European Identity, Transnational Politics, and the Origins of the European Convention (New York: Oxford University Press, 2017), 268-82.

81 Banning, 'Socialisme en Persoonlikheid', De Samenwerking. Algemeen Maandschrift, 2 (Oct. 1913-Oct. 1914), 230-9; and his first major book, Om de groei der gemeenschap (1926).

82 Banning, De Dag van Morgen. Schets van een personalistisch socialisme. Richtpunt voor de vernieuwing van ons volksleven (Amsterdam: Ploegsma, 1945), 81-2, 163-4; De Keiser, De Gijzelaars, 93-5. 
Although personalist socialism was also concerned with economic, social and political reform, the book was above all a call for a new moral way of life. Banning admitted that this would not appeal to those social democrats who could do 'without this ideological basis'. ${ }^{83}$ Banning's personalist socialism was not intended as a unifying party ideology but instead a broader attempt to overcome differences of opinion among various Christian and non-Christian groups in order to rebuild the Netherlands after the war. Banning's wife was not happy with this new terminology. When she received the manuscript of the book in 1943 she wrote to him that personalism was an elite term that would not resonate with ordinary people and would only lead to confusion. Nor did he succeed, she claimed, in differentiating the new term from religious socialism in a meaningful way. ${ }^{84}$

Among the few references in The Day of Tomorrow, those to Søren Kierkegaard and Martin Buber stand out. Banning was especially inspired by Martin Buber's Ich und Du (1923), and he quoted Buber's famous saying 'Entmenget die Menge' to argue that the individual must be released from the masses in order to establish a dialogue between human beings ('I and Thou'). ${ }^{85}$ The relationship between subject and object ('I and it') - although necessary in social intercourse - is the source of alienation in the modern world. Although one of the camp hostages was associated with the group around L'Esprit and wrote a booklet about French personalism and the Swiss philosopher Denis de Rougemont, ${ }^{86}$ Banning himself was little influenced by French personalism. He referred to a whole range of Dutch thinkers and theologians - such as his teacher Roessingh and the philosopher Philip Kohnstamm, who had published an influential booklet about 'biblical personalism' - as sources of inspiration, but there appears to be no mention of Mounier in the book. ${ }^{87}$ The Russian religious thinker Nikolai Berdyaev, who went into exile in Paris and was connected to Mounier, is occasionally mentioned. ${ }^{88}$ But Mounier himself had almost no influence on Banning and, more generally, his impact on Dutch intellectual history was rather limited. ${ }^{89}$

The idea of personalist socialism has been politically influential. The Dutch People's Movement (Nederlandse Volksbeweging) that was founded immediately after the war was strongly impacted by the idea. Besides Banning, another leading member was Willem Schermerhorn, the first Dutch prime minister after 1945. The movement supported the 'breakthrough' and a committee chaired by Banning negotiated with representatives of old pre-war parties to establish a broad, progressive political party. ${ }^{90}$ These talks would eventually result in the foundation of the Labour Party (Partij van de Arbeid) in 1946. Its first political programme, co-authored by Banning, was influenced by the ideas of personalist socialism. Accordingly, Labour's main goal was to create a 'democratic-socialist society', characterised by spiritual and political freedom, respect for fellow human beings and a democratic mentality that would enable the lives of individuals and communities to flourish. ${ }^{91}$

In his opening speech at the foundational congress of the Labour Party on 9 February 1946, Banning described how things had changed over time. The new Labour Party was no longer antinational and anti-religious. The only 'antithesis' that remained and had to be retained, as it was part of the essence of socialism, was the opposition to capitalism and dictatorship. ${ }^{92}$ Labour fully embraced the principles of democracy and human rights, as well as the idea of a planned economy

\footnotetext{
83 Banning, De Dag van Morgen, 162.

84 Van Wirdum-Banning, Banning, 156.

85 Banning, Terugblik, 54-5; Banning, De Dag van Morgen, 68-9.

86 Henk Brugmans, Denis de Rougemont en het Franse personalisme ('s-Gravenhage: D.A. Daamen, 1946). Mounier plays only a minor role in the book.

87 I have found one casual reference to Mounier: Banning, Ons Socialisme. De Partij van de Arbeid in Nederland (Amsterdam: Partij van de Arbeid, s.a. [1954]), 28.

88 Banning, De Dag van Morgen, 59.

89 A.J.M. van Weers, Staat en Persoon. De politieke filosofie van Emmanuel Mounier (Delft: Eburon, 1987), 19-26; Huijsen, Socialisme als opdracht, 93; De Keiser, De Gijzelaars van Sint Michielsgestel, 101-2.

90 Jan Bank, Opkomst en ondergang van de Nederlandse Volksbeweging (NVB) (Deventer: Kluwer, 1978).

91 Banning, Kompas. Een Toelichting op het Beginselprogramma van de Partij van de Arbeid (Amsterdam: Partij van de Arbeid, 1947), 5 (proposition 2).

92 Banning, 'Openingsrede van den voorzitter Prof. Dr. W. Banning', 7.
} 
that would provide for the needs of all. ${ }^{93}$ The envisioned order implied 'the right and obligation of the community to interfere in property relationships through socialisation or other means, should this be required by the general welfare. ${ }^{94}$ Banning also emphasised that socialism was neither a worldview nor a religion; therefore, in principle, anyone could become a member of the Labour Party.

Only a week after the foundational congress, the party executive committee decided that a new political programme had to be drawn up. Banning was a member of the committee that prepared the text and he also formulated the first draft. Many of Banning's original formulations made it into the document that was presented to the party executive in March $1947 .{ }^{95}$ The provisional programme was printed in the party's weekly (at the end of 1946, the party had 114,588 members). The 917 local Labour branches sent in more than 100 amendments, which were partially incorporated into the revised version of the programme to be discussed at the party convention of April 1947 in Utrecht. ${ }^{96}$ Banning introduced the text at the convention and chaired the general discussion. Many amendments were withdrawn on his advice. ${ }^{97}$

Afterwards Banning published the political programme, together with a commentary that repeated some of his introductory remarks at the convention. ${ }^{98}$ As did the 1937 programme of the SDAP, Labour's new political programme doubtlessly bore Banning's stamp. Two points are especially relevant here. Firstly, as Banning stressed in his commentary, moral goals were fundamental in the new programme. Although economic fairness was considered the precondition for the 'spiritual well-being of society', the moral factor was deemed crucial in the production process. ${ }^{99}$ This meant bidding a final farewell to dialectical materialism in any sense of the word. Secondly, the aspirations of the Doorbraak were materialised in the programme. Not only were the members of the committee that prepared the draft taken from the three old parties that merged into Labour, ${ }^{100}$ they also represented various worldviews and confessions in Dutch society.

The German Social Democratic Party (Sozialdemokratische Partei Deutschlands; SPD) went through a similar transformation some twelve years later, when it issued the Bad Godesberg declaration in 1959. The SPD abandoned its class-based orientation, committed itself to the reform of capitalism and appealed to the ethical ideals of fairness and solidarity. The Dutch programme, however, explicitly acknowledged the role of spiritual and religious resources. The state was said to be 'co-responsible for the best spiritual heritage of our people and is bound to ethical norms'. ${ }^{101}$ Moreover, Labour contended that the churches might consider it their task to speak publicly about issues of political and societal concern. ${ }^{102}$ This was a cautious formulation but still made it into the final text.

Furthermore, membership was said to be open to people from many different worldviews, provided that they accepted Labour's political principles. The text also referred to the close connection between world (religious) views and political insights, even going so far as to express its regard for party members who made this connection explicit in their political engagement. ${ }^{103}$ At a later stage, working groups would be founded along different confessional lines. These were all things that Banning had fought for and he must have been very pleased with the fact that Labour had renounced its anti-

\footnotetext{
93 Banning, Kompas. Een Toelichting, 7 (proposition 10) and 9-10 (about 'basic democratic rights').

94 Banning, 'Openingsrede van den voorzitter Prof. Dr. W. Banning', 12.

95 Tromp, Het sociaal-democratisch programma, 213-4.

96 Ibid., 216-8. The programme committee decided which proposals would be included in the revised version.

97 Tromp, Het sociaal-democratisch programma, 221.

98 Ibid., 222.

99 Banning, Kompas. Een Toelichting, 18 and 22-3.

100 The three parties were the SDAP, the Vrije Democratische Bond, a left-leaning liberal party, and the Christelijk-Democratische Unie, a left-wing protestant party.

101 Banning, Kompas, 9 (proposition 23).

102 Ibid., 12 (proposition 34).

103 Ibid., 12 (proposition 35).
} 
ecclesiastical stance. The party also supported members who campaigned against the old 'antithesis' the organisation of political parties along confessional lines. ${ }^{104}$

In the first election after the Second World War the Labour Party secured only twenty-nine seats in Parliament (out of 100), whereas the Catholics remained the biggest party (thirty-two seats). The Communist Party gained seven seats more than in the last pre-war election in 1937, achieving an alltime high of ten seats. The three Protestant parties together had twenty-three seats, whereas the liberal party secured only six seats in the newly established parliament. From 1946 to 1958 the country was ruled by a Catholic/Labour coalition; in 1948, Willem Drees became the first social-democratic prime minister of the Netherlands.

At that time the antithesis was still influential in Dutch politics and reached a climax in 1954 with the 'pastoral letter' (mandement) of the Dutch Catholic bishops. They defended the advantages and benefits of Catholic organisations and admonished the faithful to stay out of socialist organisations and to not vote for Labour. ${ }^{105}$ At the request of the executive committee Banning wrote a defence that could be used in Labour Party working groups. He gave a careful analysis of the development of socialism and its relationship to the various confessions. By way of conclusion he asked rhetorically whether it might not be decent to stop proclaiming that Christianity and socialism (as represented by Labour) were incompatible? ${ }^{106}$

The representatives of the Doorbraak wanted to tear down the walls between groups and were therefore outspoken critics of the system of Dutch 'pillarisation', a term commonly used in the 1950s to refer to entire complexes of societal organisations and institutions that were based on a particular worldview or confession. ${ }^{107}$ Catholic or Protestant unions, schools, football clubs and universities were examples of this system. Technically, a pillar may be described as 'a subsystem in society that links political power, social organisation and individual behaviour and which is aimed to promote in competition as well as in cooperation with other social and political groups - goals inspired by a common ideology shared by its members, for whom the pillar and its ideology is the main locus of social identification'. ${ }^{108}$ Banning fiercely criticised the process of pillarisation as deepening the divisions which Labour and the Doorbraak wanted to overcome. ${ }^{109}$ Banning had practical objections against the pillarised system: a lot of money was wasted for instance in subsidising separate Protestant, Catholic and Socialist organisations. His principal objection, however, was that the system went against the Christian message, because of the identification of belief with a particular power system. In this respect Banning remained a liberal socialist Protestant, who tried to overcome confessional differences and strived for an integrated Protestant church in the Netherlands.

104 Banning, Kompas, 29-30; see W. Thomassen, Opening van zaken. Een en ander over de voorbereiding ener Partij van de Arbeid (Amsterdam: Studiecommissie uit de S.D.A.P., 1946).

105 A.F. Manning, 'Uit de voorgeschiedenis van het mandement van 1954', Jaarboek Katholiek Documentatie Centrum, 1971 (Nijmegen 1972), 138-46 and J. Hinke, 'Het bisschoppelijk mandement 1954 in pers en politiek mei 1954-februari 1955', Jaarboek Katholiek Documentatie Centrum 1979 (Nijmegen s.a.), 73-116.

106 Banning, Ons Socialisme. De Partij van de Arbeid in Nederland. Een verweer en appèl naar aanleiding van het Mandement 1954 en de daarop gevolgde discussies (Amsterdam: Partij van de Arbeid, s.a. [1954]), 56.

107 J.P. Kruijt, 'Verzuiling in beweging? Verzuildheid in Nederland, blijvende structuur of aflopende episode?', in J. Gielen et al., Pacificatie en de zuilen (Meppel: Boom, 1965), 9-31, 12.

108 E.H. Bax, Modernisation and Cleavage in Dutch Society: A Study of Long Term Economic and Social Change (Aldershot: Avebury, 1990), 104; see Arie L. Molendijk, 'Versäulung in den Niederlanden: Begriff, Theorie, lieu de mémoire', in Friedrich Wilhelm Graf and Klaus Große Kracht, eds., Religion und Gesellschaft. Europa im 20. Jahrhundert, Industrielle Welt. Schriftenreihe des Arbeitskreises für moderne Sozialgeschichte, vol. 73 (Köln etc.: Böhlau, 2007), 307-27.

109 Banning, 'De nieuwe weg', Socialisme en Democratie, 14 (1957), 73-9, 73; see Banning, 'Verzuiling', in Banning, Om Mens en Menselijkheid in Maatschappij en Politiek (Amsterdam: Meulenhoff, 1960), 165-79. The term doorbraak is also used to denote the attempt to reform the Dutch Reformed Church (Nederlandse Hervormde Kerk) into a pluralist church; see Peter Kromdijk, Eenheid in Verscheidenheid. De doorbraak in de Nederlandse Hervormde Kerk en de samenleving tijdens het interbellum (Hilversum: Verloren, 2017). 
Today the notion of pillarisation is contested. Historical research has questioned its usefulness and it has been suggested that the word 'pillars' be replaced by the term 'heavy communities'. ${ }^{110}$ Is the whole idea of completely segregated communities simply wrong? Can the social democrats and liberals be aptly described as 'pillars'? ${ }^{111}$ Does the metaphor of pillarisation not suggest a false symmetry and uniformity between the pillars? The exact degree of participation and the alleged implicated level of mutual exclusion will probably remain contested. What is remarkable about the Dutch case, however, is the deep split in reformed Protestantism and the significant role of various Protestant political parties. New social and religious movements emerged in other countries as well, becoming politically influential and creating their own institutions and organisations. Socialists and ultramontane Catholics were important elsewhere in Europe, but Abraham Kuyper's Neo-Calvinists seem peculiar to the Netherlands. What all three movements have in common is that they were popular, engaged large numbers of people and used modern mass media such as daily newspapers, the radio and mass rallies. ${ }^{112}$

More important here is the question of whether the breakthrough was successful. The Christian political parties wielded considerable political power. Although the 1956 elections were a great success for Labour (thirty-four out of 100 seats in Parliament), making it possible for Drees to form his third cabinet, they were followed closely by the Catholic People's Party with thirty-three seats, whereas three Protestant parties together gained 20 per cent of the vote. Although the idea of Doorbraak was successfully introduced in the Labour Party, confessional parties and institutional 'pillars' remained strong until at least the late 1960s. Although most historians conclude that the Doorbraak did not succeed, it has been argued that it made an impact and put confessional parties on the defensive. The pillars may have remained more or less intact for several decades, but there was growing support for the idea that pillarisation was not good for the social cohesion of Dutch society. From the 1970 s onwards the structures of pillarisation would slowly crumble. ${ }^{113}$

In 1959, for the last time, Banning chaired the committee that prepared the draft of Labour's new political programme, which largely followed the 1947 programme. Once again, Banning introduced the debate at the 1959 party convention, and afterwards published the text, including his own commentary. Labour was again defined as an inclusive, democratic doorbraak party. ${ }^{114}$ Banning successfully opposed an amendment that stressed the need to fight against the concentration and abuse of economic power as Labour's ideological basis. ${ }^{115}$ A proposition rejecting the idea of party formation on the basis of confession was added to the new political programme. ${ }^{116}$ In sum, the new programme expressed Banning's own ideas and concerns rather effectively. ${ }^{117}$ This was the last programme that defined Labour's identity, until it no longer had any practical impact in the mid-1960s. ${ }^{118}$

$\overline{110}$ J.C.H. Blom and J. Talsma, eds., De verzuiling voorbij: godsdienst, stand en natie in de lange negentiende eeuw (Amsterdam: Spinhuis 2000); Peter van Dam, Staat van verzuiling. Over een Nederlandse mythe (Amsterdam: Wereldbibliotheek, 2011).

111 James Kennedy and Jan P. Zwemer, 'Religion in the Modern Netherlands and the Problem of Pluralism', BMGN Low Countries Historical Review, 125 (2010) 237-68.

112 Peter van Rooden, 'Secularisation, Dechristianisation and Rechristianisation in the Netherlands', in Hartmut Lehmann, ed., Säkularisierung, Dechristianisierung, Rechristianisierung im neuzeitlichen Europa. Bilanz und Perspektiven der Forschung (Göttingen: Vandenhoeck \& Ruprecht, 1997), 131-53; Arie L. Molendijk, 'Neo-Calvinist Culture Protestantism. Abraham Kuyper's Stone Lectures', Church History and Religious Culture, 88 (2008) 235-50.

113 James C. Kennedy, Nieuw Babylon in aanbouw. Nederland in de jaren zestig (Amsterdam: Boom, 1995), 29-37.

114 Tromp, Het sociaal-democratisch programma, 268.

115 Ibid., 270.

116 Ibid., 277 (art. 15).

117 Banning, 'Toelichting op het beginselprogramma 1959', in Kompas. Beginselprogramma 1959. Universele Verklaring van de Rechten van de Mens (Amsterdam: Partij van de Arbeid, 1960), 30.

118 Tromp, Het sociaal-democratisch programma, 341. The political programme of 1977 lacked a sense of direction and coherence according to Tromp. 


\section{A Successful Party Ideologue}

The above findings suggest that Banning was successful in determining the ideological course of the Dutch Labour Party. The question remains as to why he was so influential. Was he successful because he was fundamentally apolitical, as has been suggested ? $^{119}$ Was he merely the party ideologue with no significant political influence? Although he was not one of the political leaders, by writing various drafts and presiding over the debates about the political programme, he wielded real power. $\mathrm{He}$ may not have posed a threat to the party establishment because he did not aspire to party or cabinet functions, ${ }^{120}$ but he made a substantial contribution to reforming Labour into a broad, modern party that would be a major force in Dutch post-war politics. Determinist Marxist principles were abandoned and replaced by an ideology that emphasised democratic and ethical values to guide the socialist movement.

Many historians point to the Bad Godesberg declaration of the German SPD in 1959 as a watershed in the history of socialism. The Dutch socialist party, however, turned away from classical Marxism as a compulsory worldview already in the period 1946-8. Banning was the key figure in this so-called 'breakthrough' (Doorbraak), and he had the power to block attempts by other party members to reintroduce orthodox Marxist principles. Although his contribution was mainly an ideological one, he had real power as the leader of the religious socialists within the SDAP and the PvdA. The religious socialists were a minority but were nonetheless a factor to be reckoned with. Although influential in elite circles, his personalist socialism found little popular resonance, but the implied assertion of the rights of the individual and the individual's irreplaceable value did have an impact. Banning's personalist socialism was not so much inspired by Emmanuel Mounier and French personalism in general. He referred to Kierkegaard, Martin Buber and several of his teachers to argue for a 'community of persons' and the necessity to overcome the exploitation and alienation of workers.

Banning's influence is also evident in the strong responses triggered by his programme of reform. He was the object of personal attacks and was depicted as a vain man with vague ideas. Nevertheless, he became a popular member of the SDAP executive committee and was elected to many committees that would determine the course of the party. Other channels of influence were his editorships of journals and his contributions to newspapers. There was his 'own' Tijd en Taak, the principal journal of the religious socialists, but he also co-edited Socialism and Democracy, the new SDAP journal that was launched in 1939. Before being elected to the executive committee in 1931, he published and polemicised in the socialist daily The People (Het Volk). He was the director of Barchem, taught at various schools, published many books and pamphlets and travelled the country giving popular lectures. He could captivate an audience and make jokes, and he was a great debater. ${ }^{121}$ Always one to take the initiative, he wrote letters to the executive committee and drafted texts for SDAP - and later PvdA - committees, which formed the basis for discussion.

However, most authors point to his role as mediator and broker to bring various factions together as the main reason for his success. Banning was also able to popularise religious socialist thinking and mediate ideas from abroad (such as the work of Hendrik de Man). ${ }^{122}$ Sometimes his role has been reduced to that of a populariser of socialist thought. ${ }^{123}$ His crystal-clear presentations, which made things seem easy, in fact testify to his analytical and rhetorical skills, by which he brought people together and created consensus. This is not to say that he did not have outspoken opinions that he could defend vehemently, but he was no quibbler. ${ }^{124}$

\footnotetext{
119 Cohen, Om de vernieuwing van het socialisme, 239; Van Wirdum-Banning, Banning, 103.

120 L.H. Ruitenberg, 'Banning en het politieke leven', in Banning, Terugblik en perspectief, 124.

121 A good description thereof is found in C.A. Mennicke, Ons Tijdsgewricht. In de spiegel van een persoonlijk levenslot (Utrecht: Bijleveld, 1947), 187.

122 Cohen, Om de vernieuwing van het socialisme, 207, 237-8.

123 Verwey-Jonker, 'Vijf en twintig jaar socialistische theorie', 336-7.

124 J.J. Buskes, Vier vrienden (Apeldoorn: Semper Agendo, 1971), 148.
} 
It has often been claimed that Banning's work was fundamentally apolitical. I am not sure that this is the best way to characterise his contribution. Although it is true to some degree that party leaders like Albarda, Vorrink and Drees steered the party's practical course while Banning formulated its ideology, Banning was also strongly engaged in practical discussions, as the disarmament struggle showed. He was not a bystander who wrote pieces of no practical consequence, but instead did all he could to transform the SDAP into a modern democratic socialist party. He was not a power politician who forced people to do what he wanted, but he secured considerable credit and authority in the party. ${ }^{125}$ How else can we explain the fact that he was asked time and again to draft programmes and to chair party conventions? He played a significant - even leading - role in the reform of the SDAP and the PvdA from the 1930s to the late 1950s, making him a political figure in his own right.

This conclusion does not imply that the 'apolitical' label makes no sense at all. Banning did not want to become a member of parliament or a minister in the next cabinet. He could use the fact that the core of his working life lay outside politics to frame his position as being above petty party struggles. And his turn to socialist personalism in the 1940s implied a neglect of the role of power in politics, as he envisioned a kind of metapolitical form of politics that would go beyond particular class and confessional interests. This utopianism is rightly criticised, ${ }^{126}$ but he continued after 1945 as Labour's ideologue, shaping the party's ideological course. In his engagement on behalf of the Labour Party, he did not place his personal religious socialism at the forefront, but rather made compromises and thus continued to play a political role.

Acknowledgments. I would like to thank Herman Noordegraaf, the editors of this special issue, Helena Toth and Todd Weir, and the referees of this journal for their valuable remarks and criticisms of earlier versions of this article.

125 J. van de Berg, 'Bannings rol in de sociaal-democratie', Tijd \& Taak (15 May 1987), 9-13.

126 Tromp, Het sociaal-democratisch programma, 196.

Cite this article: Molendijk AL (2020). Willem Banning and the Reform of Socialism in the Netherlands. Contemporary European History 29, 139-154. https://doi.org/10.1017/S096077732000003X 